\title{
Effect of Irradiation on Sprouting of Water Yam (Dioscorea Alata) Using Different Doses of Gamma Radiation
}

\author{
James Imeh $^{1}$, M. Y. Onimisi ${ }^{1, *}$, S. A. Jonah ${ }^{2}$ \\ ${ }^{1}$ Department of physics, Nigerian Defence Academy, P.M.B 2109 Kaduna, Nigeria \\ ${ }^{2}$ Centre for Energy Research and Training (CERT), Ahmadu Bello University, Zaria, Kaduna, Nigeria
}

\begin{abstract}
Water yam (Dioscorea Alata) tuber samples from Abuja, Nigeria were irradiated with gamma radiation of doses 60, 80, 100, 120 and 140 gray respectively at an average dose rate of 3 gray/min and some un-irradiated used as control. All were monitored during storage for 7 months. Results indicated that all the un-irradiated water yams sprouted by the end of the 3rd month of storage. $90 \%$ of the irradiated water yams at 60 gray, $30 \%$ of the irradiated water yams at 80 gray and only $10 \%$ of the irradiated water yam at 100 gray sprouted within the storage period. None of the irradiated water yams at 120 and 140 gray sprouted. The results suggest that gamma radiation dose range of $100-140$ gray could effectively inhibit sprouting in water yams for 7 months. $80 \%$ of the un-irradiated water yams rotted while none of the irradiated water yams rotted within the storage period. The percentage weight loss $(64.79 \pm 13.45 \%)$ in the un-irradiated was significantly $(p \leq 0.05)$ higher than the irradiated tubers. There were no significant differences $(\mathrm{p} \leq 0.05)$ in the average values of the lipid, protein and carbohydrate content of the irradiated and un-irradiated water yam tubers. The results suggest that radiation processing preserved the quality of water yam tubers through sprout inhibition, reduction of weight loss, preservation of macronutrients such as protein, lipid, and carbohydrate content.
\end{abstract}

Keywords Water Yam, Gamma Radiation, Sprouted, Preservation, Macronutrients

\section{Introduction}

Yam is the second most important tuber crop in Africa next to cassava. Nigeria is the main producer of yam globally with $71 \%$ of world production[1]. Yams are annual or perennial tuber-bearing and climbing plants with over 600 species in which only few are cultivated for food and medicine[2]. The most cultivated species in Nigeria are the white yam (D. rotundata), yellow yam (D. cayenensis), water yam (D. alata) and trifoliate yam (D. dumetorum) [3]. The crop is of major importance in the diet and economic life of people in West Africa, the Caribbean islands, parts of Asia, and Oceania[4]. Yam is an elite crop, preferred over other root and tuber crops of West Africa and a choice during ceremonies and festivities[5].

D. alata is also referred to as greater yam, Asian greater yam and ten-month yam. It is more important as food in West Africa and the Caribbean than in Asia and the Americas where it originated, and has been competing with the most important native species, D. rotundata Poir. It was

* Corresponding author:

onimisimy@yahoo.com (M.Y. Onimisi)

Published online at http://journal.sapub.org/chemistry

Copyright (C) 2012 Scientific \& Academic Publishing. All Rights Reserved introduced to Africa some hundred years ago from Malaysia through agriculturists and by Portuguese and Spanish seafarers[6]. It is next to D. rotundata in terms of volume of production and extent of utilization. D. alata is also known for its high nutritional content[7]. D. alata tubers have variable shapes, the majority being cylindrical. The flesh of the tuber ranges in colour from white to purplish[1]. The texture of its flesh is usually not as firm as that of white yam and less suitable than other species for the preparation of the most popular food products from yam (fufu and pounded yam especially) in the West Africa region.

The production of the yam is seasonal, so storage is necessary before subsequent planting or for use as food. Fresh yam tubers are often difficult to store and are subject to deterioration by sprouting and microbial rot during storage[8]. Post-harvest losses usually range from 25 to $60 \%$ [9].

Loss of yam in storage due to sprouting is very high[10].Several inhibitory chemical growth regulators such as maleic hydrazide, Tetrachloronitro benzene, acetic acid, naphthalene have been used to retard sprouting in stored yam tubers. Apart from unavailability of the right type of chemicals and their toxicity nature, widespread adulteration of the available ones especially in Nigeria is a serious problem[11]. There are several reports on how temperature and age of the tuber affects sprouting of yam[12]. Processing of 
yams into various products including flour is a viable alternative for checking post harvest losses and promotes year round availability.

Radiation technology can complement existing technologies to ensure food security and safety[13]. Radiation processing could be used for anti-infestation of food grains and pulses; inhibition of sprouting in onions, potatoes, garlic, yam and ginger, preventing microbial contamination of spices; extending shelf-life under recommended conditions of storage; and overcoming quarantine barriers in international trade. Ionizing radiations have the potentials of reducing considerable storage losses through inhibition of sprouting, inactivation of food spoilage micro-organism, control of insects and sterilization of food crops[12]. Irradiation technology is easy to apply, clean, and environment-friendly. It is a direct, simple and efficient on-line process.

The most widely used and best traditional storage method is yam barn. However, tubers stored in this way are exposed to attack by pests and micro - organisms. Also substantial losses in weight occur mainly due to respiratory processes[14]. One method investigated for use in the small scale storage of yam is the manual removal of the bud as soon as germination or sprouting of the tuber is noticed in the yam barn. This method is found to reduce loss in weight, moisture content and carbohydrate food content but difficult to apply for large scale storage of yams. Storage at low temperatures, particularly at $15^{\circ} \mathrm{C}$, suppresses sprouting in yams. This temperature also reduces weight loss, moisture loss, respiration rate, and maintains good palatability of stored product. However, lack of regular supply of electricity, cost and high temperature tropical weather do not encourage low temperature storage technique.

Unlike most previous studies which have focused on other species or cultivars of root and tuber crops, this study investigated the potential of applying gamma irradiation for improving the quality of the major yam tuber variety in the FCT, Abuja. It was carried out to determine the influence of gamma radiation on sprouting and proximate composition of Dioscorea alata yam tubers in storage in Abuja, Nigeria.

\section{Materials and Method}

Water yam (Dioscorea alata) tuber was investigated in this research work. They were collected from Kwali in Abuja, Federal Capital Territory, Nigeria. They were carefully selected for the lack of rot or disease, serious bruises or injuries that might predispose them to spoilage. The yam tubers were divided into six groups each made of ten. Five groups were treated with gamma radiation doses of $60 \mathrm{~Gy}, 80 \mathrm{~Gy}, 100 \mathrm{~Gy}$, 120Gy and 140Gy respectively while the yam tubers in the sixth group were un-irradiated to serve as control. The yams were irradiated using a cobalt-60 source at the Gamma Irradiation Facility, Nigeria Atomic Energy Commission, Sheda, Abuja, at an average dose rate of $3 \mathrm{~Gy} / \mathrm{min}$.

\subsection{Gamma Irradiation Facility}

The Gamma Irradiation Facility (GIF)[15] at the Nuclear Technology Centre, Nigeria Atomic Energy Commission (NAEC), Sheda, Abuja, FCT, Nigeria was used for the irradiation. The facility is a multipurpose semi-commercial plant designed as a research and experimentation facility as well as for industrial purposes. It consists mainly of an irradiation room with a steel reinforced concrete walls thickness of about $1.8 \mathrm{~m}$ to house the Co- 60 radioactive sources of total current activity of about $5.5 \times 10^{15} \mathrm{~Bq}(170 \mathrm{kCi})$, a continuous overhead conveyor transport system for large products and six different modes of operation (sample elevator, stationary irradiation, swiveling device, two-inner path, two-outer path and four path irradiation). The choice of the mode of operation depends on type of product, quantity of product, shape, size, bulk density and the required dose. Uniform irradiation and accurate computer controlled irradiation dosage are ensured in all the modes of operations and as much as 18 metric tons of products could be irradiated in a single batch irradiation using four-path irradiation mode of operation. For this study irradiation was carried out in the stationary mode of operation with the possibility of varying dose rates $(0.05-5 \mathrm{kGy}$ per $\mathrm{hr})$ depending on the location and distance from the source.

\subsection{Measurement of Absorbed Dose}

The Bruker e-scan alanine dosimetry reader system which provides a reliable means of measuring the absorbed dose based on the generation of specific stable radicals in crystalline alanine by ionizing radiation was used to measure the absorbed dose.

\subsection{Sprouting Measurement}

The yam tubers were marked for easy identification and observed in an open store with ambient temperature for seven months. The tubers were carefully examined every week for the appearance of fresh shoots to indicate sprouting. Records were made of the sprouting tubers.

\subsection{Observation of Rotting}

Similarly, yam tubers were carefully examined every week for the appearance of soft spots and wet surfaces to determine point rotting and records were made.

\subsection{Weight Loss Measurement}

The weight masses of all the yam tubers were also measured and recorded before and immediately after irradiation and on a monthly basis for seven months.

\subsection{Proximate Analysis}

The proximate composition (moisture content, ash content, crude lipid content, crude fibre content, protein content and carbohydrate content) of the yam tuber was determined using the standard methods of [16]. This was carried out in the Chemistry Advanced Laboratory, Sheda Science and Tech- 
nology Complex, Sheda, Abuja, Nigeria.

\subsection{Statistical Analysis}

All analyses were performed in triplicates. Results were expressed by means of \pm SD. Statistical significance was established using Analysis of Variance (ANOVA) models to estimate the effect of gamma irradiation on proximate composition of water yam (D.alata) tubers. Means were separated according to Duncan's multiple range analysis ( $\mathrm{P}$ $\leq 0.05$ ), with the help of the software |SPSS 16.0.

\subsection{Results and Discussion}

Results on the effects of irradiation and storage on sprouting is presented in Table 1. It was observed that by the end of the third month of storage, all the un-irradiated yams had sprouted. The irradiated yams however did not start sprouting until the third month. At the end of the storage period (7 months), $90 \%$ of the irradiated yams at $60 \mathrm{~Gy}$ had sprouted. $30 \%$ of the irradiated yams at $80 \mathrm{~Gy}$ had sprouted. Only $10 \%$ of the irradiated yam at $100 \mathrm{~Gy}$ sprouted. The irradiated yams at $120 \mathrm{~Gy}$ and $140 \mathrm{~Gy}$ did not sprout. This shows that a dose range of $100 \mathrm{~Gy}-140 \mathrm{~Gy}$ will completely inhibit sprouting in water yam.

\subsection{Rotting}

Results on the effects of irradiation and storage on rotting is presented in Table 2. At the end of the storage period $80 \%$ of the un-irradiated yam rotted while none of the irradiated yams rotted. It was observed that the rotting in the un-irradiated water yams increased with storage time

\subsection{Reduction of Weight Loss}

The initial mean weight $(\mathrm{Kg})$, final mean weight $(\mathrm{Kg})$ after 7 months, the weight loss $(\mathrm{Kg})$ and percentage (\%) weight loss of the water yam tubers after 7 months are listed in Table 3. After 7 months the un-irradiated (control) water yam tubers had significant loss in weight with percentage losses of $64.79 \pm 13.45 \%$. Also the yam tubers irradiated with the dose of 60 Gy and 80 Gy had weight loss of $38.31 \pm 10.59 \%$ and $37.36 \pm 7.45 \%$ respectively. The weight losses in the yam tubers irradiated at doses of $100 \mathrm{~Gy}, 120 \mathrm{~Gy}$ and $140 \mathrm{~Gy}$ are significantly reduced to $23.19 \pm 8.71 \%, 18.32 \pm 5.64 \%$ and $17.27 \pm 5.45 \%$ respectively. These indicate that radiation treatment of water yam tubers preserves the freshness of the tubers during storage to a great extent when compared with the untreated tubers used as control. Yams stored for a period of time become dehydrated, fibrous and eventually undergo physical and quality loss[12].

\subsection{Proximate Analysis}

The percentage moisture content, ash content, crude lipid content, crude fibre content, crude protein content and car- bohydrate content of water yam (D.alata) tubers before irradiation, immediately after irradiation and after seven months of storage are listed in Tables 4, 5 and 6 respectively.

After seven months of storage the moisture contents are significantly higher in the irradiated water yam tubers than the control. The moisture contents of the water yam ranged between $2.40 \pm 0.100$ to $3.37 \pm 0.058 \%$ immediately after irradiation and between $6.24 \pm 0.377$ to $8.04 \pm 0.279 \%$ in the irradiated tubers after seven months of storage as compared to $5.56 \pm 0.919 \%$ in the control. Although it has been observed that tuber moisture content varies considerably among species, harvest date and length of storage[17], it is evident from this work that radiation retains to a large extent the moisture content of the yam tuber during storage. This is an indication that radiation processing of yam tubers could preserve the qualities, such as, freshness from the observed high moisture content of irradiated yam tubers after seven months of storage.

The Ash content, which is associated with mineral content in water yam tubers remain almost un-affected by radiation processing. It remained almost un-affected immediately after irradiation with a range of $3.26 \pm 0.233$ to $4.18 \pm 0.221 \%$ and slightly higher after seven months of storage with values ranging between $3.99 \pm 0.163$ to $4.91 \pm 0.266 \%$ when compared with $3.97 \pm 0.153 \%$ in the control. Radiation processing does not affect the mineral composition of irradiated yam tubers.

After seven months of storage it was observed that the lipid and protein contents were slightly higher in the irradiated water yam tubers than the control. The lipid content ranged between $0.99 \pm 0.020$ to $1.12 \pm 0.072 \%$ immediately after irradiation and between $1.13 \pm 0.012$ to $1.18 \pm 0.063 \%$ after seven months of storage while the value of the control was $1.1 \pm 0.016 \%$. Similarly the protein contents were higher in the irradiated water yam tubers after seven months of storage than the control. The protein content ranged between $3.52 \pm 0.406$ to $5.25 \pm 0.440 \%$ immediately after irradiation and $4.22 \pm 0.230$ to $5.08 \pm 0.503 \%$ after seven months of storage while the value of the control was $4.13 \pm 0.252 \%$. This is an indication that radiation processing preserves the lipid and protein contents in the irradiated tubers. When yam sprouts in storage, it utilizes stored food to support the sprouting. The result is increase in metabolic activity which leads to increase in respiration and loss of quality.

There was no observed significant difference in the crude fibre content of the water yam after seven months of storage. It ranged between $0.40 \pm 0.006$ to $0.75 \pm 0.031 \%$ immediately after irradiation and $0.84 \pm 0.075$ to $0.97 \pm 0.031 \%$ after seven months of storage while the value of the control was $0.78 \pm 0.010 \%$. The carbohydrate contents ranged between $86.61 \pm 0.466$ to $88.71 \pm 0.196 \%$ immediately after irradiation and between $80.96 \pm 0.720$ to $84.22 \pm 0.211 \%$ after seven months of storage. While the value for the control was $85.23 \pm 1.298$. 
Table 1. Sprouting Of Water Yam (D.Alata) During Storage

\begin{tabular}{|c|c|c|c|c|c|c|c|c|c|c|c|c|}
\hline \multirow[b]{2}{*}{ 泀 } & \multirow[b]{2}{*}{$\begin{array}{l}\underset{0}{0} \\
\underset{0}{0} \\
\stackrel{0}{0}\end{array}$} & \multirow[b]{2}{*}{$\underset{\stackrel{\Xi}{E}}{\stackrel{\vec{E}}{E}}$} & \multirow[b]{2}{*}{$\begin{array}{c}\text { Initial No. } \\
\text { of Yams }\end{array}$} & \multicolumn{7}{|c|}{ Number Sprouted Per Month } & \multirow[b]{2}{*}{ 芜 } & \multirow{2}{*}{ 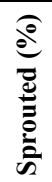 } \\
\hline & & & & 1st & 2nd & 3rd & 4th & 5th & 6th & 7 th & & \\
\hline A & 60 & irradiated & 10 & - & - & 2 & 3 & 2 & 2 & - & 9 & 90 \\
\hline B & 80 & irradiated & 10 & - & - & - & 1 & 1 & 1 & - & 3 & 30 \\
\hline $\mathrm{C}$ & 100 & irradiated & 10 & - & - & - & - & - & 1 & - & 1 & 10 \\
\hline $\mathrm{D}$ & 120 & irradiated & 10 & - & - & - & - & - & - & - & - & 0 \\
\hline $\mathrm{E}$ & 140 & irradiated & 10 & - & - & - & - & - & - & - & - & 0 \\
\hline $\mathrm{F}$ & 0 & Un-irradiated & 10 & 2 & 6 & 2 & - & - & - & - & 10 & 100 \\
\hline
\end{tabular}

Table 2. Rotting of Water Yam (D.Alata) During Storage

\begin{tabular}{|c|c|c|c|c|c|c|c|c|c|c|c|c|}
\hline \multirow[b]{2}{*}{ מूँ } & \multirow{2}{*}{$\begin{array}{l}\underset{B}{0} \\
\stackrel{0}{0} \\
\stackrel{0}{0}\end{array}$} & \multirow{2}{*}{ 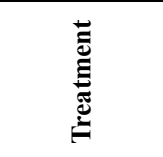 } & \multirow[b]{2}{*}{$\begin{array}{c}\text { Initial No. } \\
\text { of Yams }\end{array}$} & \multicolumn{7}{|c|}{ Number rotted Per Month } & \multirow[b]{2}{*}{ है } & \multirow{2}{*}{ 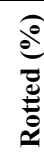 } \\
\hline & & & & 1st & 2nd & 3rd & 4th & 5 th & 6th & 7th & & \\
\hline A & 60 & irradiated & 10 & - & - & - & - & - & - & - & 0 & 0 \\
\hline $\mathrm{B}$ & 80 & irradiated & 10 & - & - & - & - & - & - & - & 0 & 0 \\
\hline $\mathrm{C}$ & 100 & irradiated & 10 & - & - & - & - & - & - & - & 0 & 0 \\
\hline $\mathrm{D}$ & 120 & irradiated & 10 & - & - & - & - & - & - & - & 0 & 0 \\
\hline E & 140 & irradiated & 10 & - & - & - & - & - & - & - & - & 0 \\
\hline $\mathrm{F}$ & 0 & Un-irradiated & 10 & - & - & 1 & 3 & 2 & 1 & 1 & 8 & 80 \\
\hline
\end{tabular}

Table 3. Weight Loss of Irradiated and Control Water Yam (D.Alata) During Storage

\begin{tabular}{|c|c|c|c|c|c|}
\hline \multirow{2}{*}{ 范 } & \multirow[b]{2}{*}{$\begin{array}{l}\text { Absorbed dose } \\
\text { (Gy) }\end{array}$} & \multirow{2}{*}{$\begin{array}{c}\text { Mean Initial Weight } \\
\left(\text { Kg) } 1^{\text {st }} \text { day }\right. \\
\text { of storage }\end{array}$} & \multicolumn{3}{|c|}{7 Months After Storage } \\
\hline & & & $\begin{array}{l}\text { Mean Final } \\
\text { Weight (Kg) }\end{array}$ & Weight Loss (Kg) & Mean \% Weight Loss \\
\hline $\mathrm{F}$ & 0 (Control) & $1.61 \pm 0.66$ & $0.60 \pm 0.44$ & $1.01 \pm 0.22$ & $64.79 \pm 13.45$ \\
\hline $\mathrm{A}$ & 60 & $1.56 \pm 0.50$ & $1.01 \pm 0.55$ & $0.55 \pm 0.05$ & $38.31 \pm 10.59$ \\
\hline B & 80 & $1.41 \pm 0.32$ & $0.92 \pm 0.31$ & $0.49 \pm 0.01$ & $37.36 \pm 7.45$ \\
\hline $\mathrm{C}$ & 100 & $1.32 \pm 0.69$ & $1.09 \pm 0.67$ & $0.23 \pm 0.02$ & $23.19 \pm 8.71$ \\
\hline $\mathrm{D}$ & 120 & $1.38 \pm 0.41$ & $1.16 \pm 0.37$ & $0.22 \pm 0.04$ & $18.32 \pm 5.64$ \\
\hline E & 140 & $1.53 \pm 0.47$ & $1.30 \pm 0.45$ & $0.23 \pm 0.02$ & $17.27 \pm 5.45$ \\
\hline
\end{tabular}

Table 4. Proximate Composition of D.Alata before Irradiation

\begin{tabular}{|c|c|c|c|c|c|c|c|}
\hline हूँ & \begin{tabular}{l} 
B. \\
\multirow{0}{0}{} \\
0
\end{tabular} & 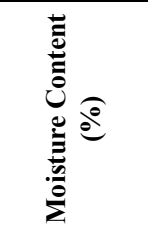 & 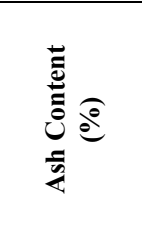 & 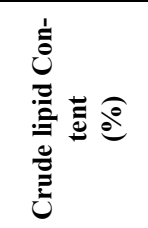 & 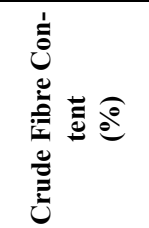 & 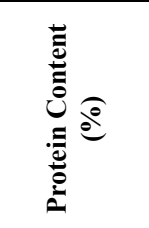 & 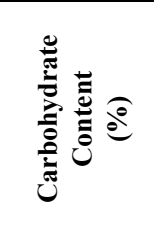 \\
\hline $\mathrm{F}$ & 0 & $5.56 \pm 0.919$ & $3.97 \pm 0.153$ & $1.11 \pm 0.016$ & $0.78 \pm 0.010$ & $4.13 \pm 0.252$ & $85.23 \pm 1.298$ \\
\hline
\end{tabular}

Table 5. Proximate Composition of D.Alata Immediately After Irradiation

\begin{tabular}{|c|c|c|c|c|c|c|c|}
\hline 离 & 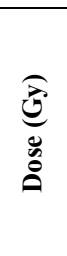 & 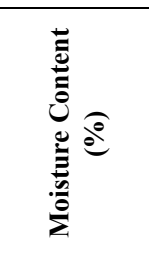 & 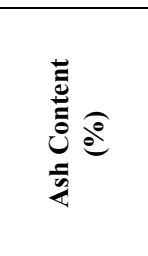 & 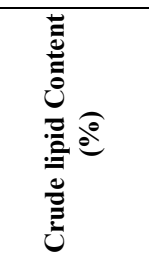 & 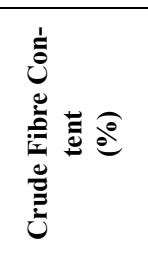 & 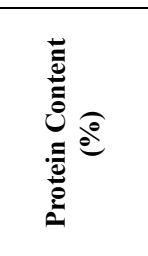 & 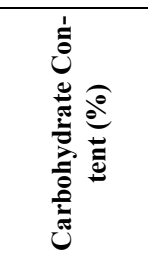 \\
\hline A & 60 & $3.37 \pm 0.058$ & $4.10 \pm 0.145$ & $1.10 \pm 0.025$ & $0.57 \pm 0.052$ & $4.82 \pm 0.425$ & $86.61 \pm 0.466$ \\
\hline $\mathrm{B}$ & 80 & $2.80 \pm 0.200$ & $4.18 \pm 0.221$ & $1.12 \pm 0.072$ & $0.42 \pm 0.021$ & $3.52 \pm 0.406$ & $88.38 \pm 0.467$ \\
\hline $\mathrm{C}$ & 100 & $2.87 \pm 0.231$ & $3.99 \pm 0.391$ & $1.07 \pm 0.021$ & $0.40 \pm 0.006$ & $5.25 \pm 0.440$ & $86.82 \pm 0.654$ \\
\hline $\mathrm{D}$ & 120 & $3.30 \pm 0.100$ & $3.26 \pm 0.233$ & $1.06 \pm 0.010$ & $0.75 \pm 0.031$ & $3.67 \pm 0.289$ & $88.71 \pm 0.196$ \\
\hline$E$ & 140 & $2.40 \pm 0.100$ & $3.74 \pm 0.105$ & $0.99 \pm 0.020$ & $0.52 \pm 0.036$ & $4.96 \pm 0.910$ & $87.91 \pm 1.123$ \\
\hline
\end{tabular}


Table 6. Proximate Composition of D.Alata 7 Months after Irradiation

\begin{tabular}{|c|c|c|c|c|c|c|c|}
\hline 音 & $\begin{array}{l}\text { S. } \\
\stackrel{0}{0} \\
0 \\
0\end{array}$ & 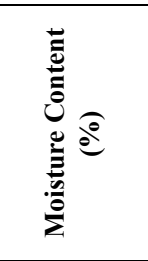 & 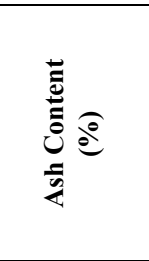 & 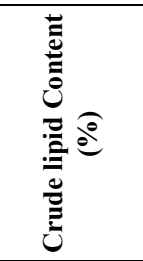 & 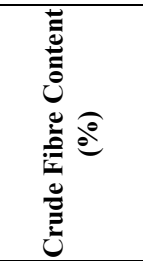 & 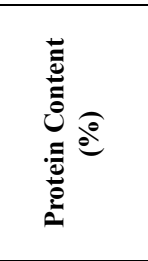 & 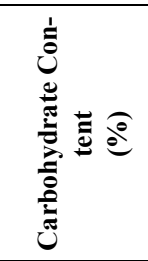 \\
\hline A & 60 & $6.24 \pm 0.377$ & $4.06 \pm 0.02$ & $1.13 \pm 0.012$ & $0.84 \pm 0.075$ & $4.44 \pm 0.154$ & $84.13 \pm 0.378$ \\
\hline $\mathrm{B}$ & 80 & $7.88 \pm 0.081$ & $4.30 \pm 0.521$ & $1.15 \pm 0.132$ & $0.89 \pm 0.012$ & $4.22 \pm 0.230$ & $82.44 \pm 0.787$ \\
\hline $\mathrm{C}$ & 100 & $6.38 \pm 0.155$ & $3.99 \pm 0.163$ & $1.15 \pm 0.047$ & $0.87 \pm 0.085$ & $4.26 \pm 0.145$ & $84.22 \pm 0.211$ \\
\hline $\mathrm{D}$ & 120 & $8.01 \pm 0.061$ & $4.91 \pm 0.266$ & $1.18 \pm 0.063$ & $0.97 \pm 0.031$ & $4.94 \pm 0.410$ & $80.96 \pm 0.720$ \\
\hline $\mathrm{E}$ & 140 & $8.04 \pm 0.279$ & $4.04 \pm 0.066$ & $1.16 \pm 0.061$ & $0.95 \pm 0.072$ & $5.08 \pm 0.503$ & $81.68 \pm 0.248$ \\
\hline
\end{tabular}

\section{Conclusions}

This study clearly demonstrates that gamma radiation at the dose of 100-140 Gy will effectively inhibit sprouting in water yam (Dioscorea alata) tubers. Radiation processing at doses of $100 \mathrm{~Gy}$ above can preserve the quality of the water yam tubers through sprout inhibition, reduction of weight loss and preservation of food values such as lipid, protein and carbohydrate.

Irradiation treatment is recommended for large scale storage of water yam tubers and other food produce for sprout inhibition, extension of shelf-life, reduction of microbial load and preservation of nutritional qualities. Increased radiation food processing will enable farmers to grow more food, which will translate into more money to the rural population (about $75 \%$ of Nigerians) and market conditions that will offer high farm incomes.

With more money, farmers are more likely to diversify production and produce value added produce particularly for export which will benefit not only the farmers but the Nigerian economy as a whole.

\section{REFERENCES}

[1] FAO (2002). Food and Agricultural organization FAOSTAT Data. FAO, Rome Italy IITA (2006). Yam. Research Review. International Institute of Tropical Agriculture, Ibadan, Nigeria. Pp.1-4.

[2] IITA. "Yam research review". International institute of tropical agriculture, Ibadan, Nigeria. 2006:1-4.

[3] Amusa N.A. et al (2003). "Yam disease and its management in Nigeria". Afr. J. Biotechnol.,2:497-502

[4] Giranrdin, O. et al. (1998). "Effect of storage on system and sprout removal on post harvest yam (Dioscorea Spp) fresh weight losses". Journal of Agric. Sci. 130: 329-336.
[5] Hahn, S.K. et al (1987). "Yam production and its future prospects". Outlook on Agriculture, 16 (3):105-110.

[6] Martin, F. W., (1976). "Tropical yams and their potential". Part 3. Dioscorea alata. USDA Agriculture Handbook no. 495, $40 \mathrm{pp}$.

[7] Osagie A.U. (1992). The yam tuber in storage. Post Harvest Research Unit, University of Benin, Nigeria pp. 107-173.

[8] Passam, H.C. (1977). Deterioration of yam and cassava during storage. Ann. Appl. Biology 85: 436-440

[9] Afoakwa E. O. and Sefa-Dedeh, S. (2001). Chemical composition and quality changes occurring in Dioscorea dumetorum Pax tubers after harvest. Food Chem. 75: 85-91.

[10] Medoua, G.N, Mbome I.L, Agbor-Egbe T, Mbofung C.M.F (2005). Physicochemical changes occurring during post-harvest hardening of trifoliate yam (Dioscorea dumetorum) tubers. Food Chem. 90: 597-601.

[11] David, M (2009). Nigeria: Food and Agricultural Import and Standards. USAD Foreign Agricultural Services Gain Report. Global Agricultural Information Network. Pp 1-9.

[12] Bansa, D and V. Appiah (1999). The effect of irradiation on the storage yam in Ghana. Journal the Ghana Science Association. Vol. 1 (3) pp. 100-103

[13] International consultative group on food irradiation (ICGFI). Facts about food irradiation (1999).

[14] Bhandari, M. R. Kawabata, J., Kassi, T (2003). Nutritional evaluation of wild (Dioscorea spp.) tubers of Nepal. Food Chem, 80: 619-623.

[15] Oyeyinka, O.D. and Adesanmi, C. A., (2008). "Radiation processing in promoting and ensuring food security in Nigeria". Nigeria society of engineers, 2008.

[16] A.O.A.C. (2005) Official methods of Analysis of the Association of Analytical Chemist 15th Ed. Vol. 2. Kenneth Helrich Washington.DC pp. 125-576

[17] Babajide J. M., Henshaw F. O., and Oyewole O. B. (2008). Effect of yam variety on the pasting properties and sensory attributes of traditional dry-yam and its products.Journal of Food Quality Vol. 31(3), Pp. 295-305 